2015-06

\title{
Calcification is not the Achilles' heel of cold-water corals in an acidifying ocean
}

Rodolfo-Metalpa, $\mathrm{R}$

http://hdl.handle.net/10026.1/3912

10.1111/gcb. 12867

Global Change Biology

Wiley

All content in PEARL is protected by copyright law. Author manuscripts are made available in accordance with publisher policies. Please cite only the published version using the details provided on the item record or document. In the absence of an open licence (e.g. Creative Commons), permissions for further reuse of content should be sought from the publisher or author. 
Received Date : 22-Jun-2014

Revised Date : 16-Dec-2014

Accepted Date : 18-Dec-2014

Article type : Primary Research Articles

\title{
Calcification is not the Achilles' heel of cold-water corals in an acidifying ocean
}

\author{
Riccardo Rodolfo-Metalpa ${ }^{1,2 *}$, Paolo Montagna ${ }^{3}$, Stefano Aliani ${ }^{4}$, Mireno Borghini ${ }^{4}$, \\ Simonepietro Canese ${ }^{5}$, Jason M. Hall-Spencer ${ }^{6}$, Andy Foggo $^{6}$, Marco Milazzo $^{7}$, Marco Taviani ${ }^{3,8}$ \\ and Fanny Houlbrèque ${ }^{1,2}$
}

1. Institut de Recherche pour le Développement, UR 227 CoReUs 2, Nouméa, New Caledonia

2. International Atomic Energy Agency -Marine Environment Laboratories, 4 Quai Antoine $1^{\text {er }} 98000$, Principality of Monaco

3. Istituto di Scienze Marine (ISMAR), Consiglio Nazionale delle Ricerche, Via Gobetti 101, 4029 Bologna

4. Istituto di Scienze Marine (ISMAR), Consiglio Nazionale delle Ricerche, Forte S.Teresa, 19036 La Spezia

5. Italian National Institute for Environmental Protection and Research (ISPRA), Via Brancati 60, 00144 Roma, ITALY

6. Marine Biology and Ecology Research Centre, School of Marine Science \& Engineering, Plymouth University, UK

7. Department of Earth and Marine Sciences, Co.N.I.S.Ma., University of Palermo, Palermo, Italy.

8. Biology Department, Woods Hole Oceanographic Institution, 266 Woods Hole Road, Woods Hole, MA 02543, USA

Corresponding author: Riccardo Rodolfo-Metalpa, riccardo@rodolfo-metalpa.com

Running head: Cold-water corals resilience to acidification

This article has been accepted for publication and undergone full peer review but has not been through the copyediting, typesetting, pagination and proofreading process, which may lead to differences between this version and the Version of Record. Please cite this article as doi: 10.1111/gcb. 12867

This article is protected by copyright. All rights reserved. 
Keywords: Cold-water corals; ocean acidification; calcification and dissolution; Desmophyllum dianthus; Caryophyllia smithii; Dendrophyllia cornigera.

\begin{abstract}
Ocean acidification is thought to be a major threat to coral reefs: laboratory evidence and $\mathrm{CO}_{2}$ seep research has shown adverse effects on many coral species, although a few are resilient. There are concerns that cold-water corals are even more vulnerable as they live in areas where aragonite saturation $\left(\Omega_{\text {ara }}\right)$ is lower than in the tropics and is falling rapidly due to $\mathrm{CO}_{2}$ emissions. Here, we provide laboratory evidence that net (gross calcification minus dissolution) and gross calcification rates of three common cold-water corals, Caryophyllia smithii, Dendrophyllia cornigera and Desmophyllum dianthus, are not affected by $p \mathrm{CO}_{2}$ levels expected for 2100 $\left(p \mathrm{CO}_{2} 1058 \mu \mathrm{atm}, \Omega_{\text {ara }} 1.29\right)$, and nor are the rates of skeletal dissolution in $D$. dianthus. We transplanted $D$. dianthus to $350 \mathrm{~m}$ depth $\left(\mathrm{pH}_{\mathrm{T}} 8.02 ; p \mathrm{CO}_{2} 448 \mu \mathrm{atm}, \Omega_{\text {ara }} 2.58\right)$ and to a $3 \mathrm{~m}$ depth $\mathrm{CO}_{2}$ seep in oligotrophic waters $\left(\mathrm{pH}_{\mathrm{T}} 7.35 ; p \mathrm{CO}_{2} 2879 \mu \mathrm{atm}, \Omega_{\text {ara }}\right.$ 0.76) and found that the transplants calcified at the same rates regardless of the $p \mathrm{CO}_{2}$ confirming their resilience to acidification, but at significantly lower rates than corals that were fed in aquaria. Our combination of field and laboratory evidence suggests that ocean acidification will not disrupt cold-water coral calcification although falling aragonite levels may affect other organismal physiological and/or reef community processes.
\end{abstract}

\title{
Introduction
}

Cold-water corals (CWC) occur from tropical to polar waters, from the shallows to the deep sea and a few build extensive reefs that attract fish and a high diversity of associated invertebrates (Roberts et al., 2009). Despite their diversity and ecological importance we know much less about CWC biogeography than their tropical counterparts. There is a growing body of work on their metabolism, based on monitoring corals in refrigerated aquaria (Dodds et al., 2007; Tsounis et al., 2010; Naumann et al., 2011), but it is difficult to know how these results relate to corals in the wild since very few studies have investigated their metabolism in situ. Field studies have the advantage of being more ecologically realistic, incorporating natural fluctuations in biotic and

This article is protected by copyright. All rights reserved. 
abiotic conditions, but are less constrained and logistically more difficult to perform than laboratory experiments. A lack of in situ data on the physiological response of CWC to environmental variations has hindered our ability to project their fate in the face of rising $\mathrm{CO}_{2}$ levels. Ocean acidification is reducing the amount of carbonate ions $\left[\mathrm{CO}_{3}{ }^{2-}\right]$ available in seawater (Orr et al., 2005), therefore lowering the $\mathrm{CaCO}_{3}$ saturation state towards undersaturated levels $(\Omega$ $<1$ ). It is believed, but a matter of debate (McCulloch et al., 2012a), that a decrease in the $\left[\mathrm{CO}_{3}{ }^{2-}\right]$ in seawater as oceans acidify will reduce coral calcification rates and increase skeletal dissolution (Langdon et al., 2000; Fabricius et al., 2011). Some predict that tropical coral reefs will stop calcifying this century (Hoegh-Guldberg et al., 2007) and others expect that reef-building scleractinian calcification rates will decrease by $17-37 \%$ due to a doubling of preindustrial levels of $p \mathrm{CO}_{2}$ (Erez et al., 2011).

It is predicted that ca. $70 \%$ of known CWC reefs will be exposed to waters that are corrosive to aragonite before the end of 2100 (Guinotte et al., 2006; Tittensor et al., 2010; Jackson et al., 2014). Here, we assess this issue since many CWC species already live at depths well below the aragonite saturation horizon (Thresher et al., 2011; Lunden et al., 2013) and form habitats at around $\Omega_{\text {ara }}=1$ in Chilean fjords (Försterra \& Häusserman, 2003).

We combined laboratory and field experiments to investigate responses of Caryophyllia smithii, Desmophyllum dianthus and Dendrophyllia cornigera to waters acidified with $\mathrm{CO}_{2}$. Caryophyllia smithii and D. dianthus are two of the commonest solitary corals in Atlantic Ocean and the Mediterranean Sea; Dendrophyllia cornigera forms colonies and is widespread in the Mediterranean, it also occurs in the Atlantic from Cape Verde and the Azores north to the Bay of Biscay.

Research into the effects of acidification on CWCs in aquaria has provided conflicting results. Form \& Riebesell (2012) found a significant decrease in the net calcification of Lophelia pertusa during a one week exposure to high $\mathrm{CO}_{2}$ levels but found that this reef-forming coral was able to acclimate in the long-term (6 months), increasing its calcification rate in seawater that was undersaturated with respect to aragonite compared to saturated conditions. Work on other CWC revealed that their calcification was not affected by acidification during the first 182 and 240 days of incubation (Movilla et al., 2014a; Carreiro-Silva et al., 2014 respectively). On the other hand, D. dianthus had a $70 \%$ reduction in skeletal growth rate after 314 days whereas Dendrophyllia

This article is protected by copyright. All rights reserved. 
cornigera showed no differences between treatments (Movilla et al., 2014a). Other studies have shown that calcification rates of L. pertusa and Madrepora oculata (which also forms deep-water reefs) were unaffected by future projected $p \mathrm{CO}_{2}$ levels in short- (hours-days; Maier et al., 2012) and long-term (weeks-months; Maier et al., 2013a,b) experiments. McCulloch et al. (2012b) showed that CWCs are able to calcify at or close to the aragonite saturation horizon by elevating their internal $\mathrm{pH}$, thus buffering external changes in seawater $\mathrm{pH}$. These studies imply that shoaling of the aragonite saturation horizon may not cause the dramatic declines in coral calcification rates that were first feared (Guinotte et al., 2006; Jackson et al., 2014). However, to what extent undersaturated seawater might affect reef integrity by increasing the dissolution of exposed coral skeletons has not yet been investigated and all studies showing that they maintain calcification rates at high $p \mathrm{CO}_{2}$ levels have been carried out in aquaria where feeding may have artificially boosted their energy reserves, likely altering responses to acidification.

In this study we first measured the effects of acidification on the net and gross calcification rates as well as the respiration rates of three CWC species cultured in aquaria under present and Representative Concentration Pathway (RCP) $8.5 \mathrm{pCO}_{2}$ scenario (IPCC, 2014). In addition, we quantified skeletal dissolution rates of $D$. dianthus maintained in aquaria during two-month incubations at present and high $p \mathrm{CO}_{2}$ levels. Finally, we compared the calcification rate of $D$. dianthus fed in aquaria in aragonite saturated conditions with those of corals transplanted into undersaturated and saturated conditions off Italy.

\section{Materials and methods}

\section{Coral collection and aquaria}

Corals were collected using a mini-dredge during three oceanographic cruises. Sixteen samples of Caryophyllia smithii were collected in December 2008 in the Bari Canyon (South Adriatic Sea; 39²7.97' N; 18²3.29' E; ca. $600 \mathrm{~m}$ depth) during the ARCO cruise (R/V Urania, CNR, Italy). In December 2009, hundreds of Desmophyllum dianthus found growing on an abandoned fishing net, were collected at $830 \mathrm{~m}$ depth off Malta $\left(36^{\circ} 44.30^{\prime} \mathrm{N} ; 1^{\circ} 58.48^{\prime} \mathrm{E}\right)$ on the MEDCOR cruise (R/V Urania, CNR, Italy). Finally, three branches of Dendrophyllia cornigera with ca. 20 polyps were retrieved from the Ionian Sea (39 50.49' N; 16 48.70' E) at $126 \mathrm{~m}$ depth in August 2009, using an ROV operated from R/V Astrea (ISPRA, Italy). These corals were maintained in large, shaded seawater containers held at $13-14^{\circ} \mathrm{C}$ on board. Seawater was renewed daily, and

This article is protected by copyright. All rights reserved. 
continuously mixed with a submersible water pump. At the end of the cruises, the samples were transported to the International Atomic Energy Agency laboratory in Monaco. During the ARCO and MEDCOR cruises, seawater samples next to living corals were collected with a CTD-Rosette system equipped with 12-1 Niskin bottles. Depth profiles of temperature, salinity and dissolved oxygen were also acquired. Seawater $\mathrm{pH}$ was immediately measured on board (see below for further details) and subsamples for total alkalinity were stored.

The corals were maintained for several months in the dark in flow-through 5001 aquaria held at $13.2^{\circ} \mathrm{C}$. The aquaria were supplied with filtered seawater pumped from $30 \mathrm{~m}$ depth at a turnover rate of $20 \%$ volume $\mathrm{h}^{-1}$. The corals were fed twice per week with frozen krill or freshly hatched Artemia nauplii. All corals appeared healthy with polyps expanded. For D. cornigera, 4-6 cm long single polyps were separated from the mother colonies using pliers and attached to tagged plastic plates using epoxy glue (HoldFast ${ }^{\circledR}$, Ohio, USA). Sixteen specimens of both D. cornigera and $C$. smithii, and 80 corallites of $D$. dianthus were prepared for the experiment in aquaria. As we wanted to examine calcification rates we selected specimens with similar skeletal mass weight (see Carreiro-Silva et al., 2014). Samples were randomly assigned to four 20-1 experimental tanks (two tanks for each $\mathrm{pH}$ treatment), continuously filled with seawater at $13^{\circ} \mathrm{C}$ with a turnover rate of $10 \% \mathrm{~h}^{-1}$. Tanks were also placed in large aquaria containing seawater kept a $13^{\circ} \mathrm{C}$ that served as water baths. Each tank contained four samples of D. cornigera and C. smithii, and 20 samples of $D$. dianthus which were positioned on the bottom of the tank in a vertical position. To measure skeletal dissolution, 24 dead $D$. dianthus skeletons were scrubbed clean in seawater and placed in each tank (four specimens for each tank, $n=8$ per treatment). These samples had white bare skeletons and appeared normal (not corroded or bored). A submersible pump (micro-jet MC 320, Mentor, $\mathrm{OH}$, USA; flow rate ca $300 \mathrm{l} \mathrm{h}^{-1}$ ) provided water circulation inside the tanks. Corals were acclimated for one month to experimental conditions (see Table 1 for seawater parameters). Then, two tanks were set up at ambient $\mathrm{pH}$ and $p \mathrm{CO}_{2}\left(\mathrm{pH}_{\mathrm{T}}=8.07 ; p \mathrm{CO}_{2}=319 \mu \mathrm{atm}\right)$, and the other two at levels projected by the end of the century $\left(\mathrm{pH}_{\mathrm{T}}=7.70 ; p \mathrm{CO}_{2}=1058 \mu \mathrm{atm}\right)$. The $\mathrm{pH}$ was controlled using a pH-stat system (IKS, Karlsbad, accuracy $\pm 0.05 \mathrm{pH}$ unit) by bubbling pure $\mathrm{CO}_{2}$ into each tank that was continuously aerated with $\mathrm{CO}_{2}$-free air. Colonies were maintained under these $p \mathrm{CO}_{2}$ conditions for three months.

This article is protected by copyright. All rights reserved. 


\section{Transplantation}

In February 2010, 22 specimens (11 per site) of $D$. dianthus were weighed and fixed onto individual plates then transplanted onto a rocky seabed at $\mathrm{CO}_{2}$ seeps off Ischia (Italy; $40^{\circ} 43.84^{\prime}$ $\left.\mathrm{N} ; 3^{\circ} 57.08^{\prime} \mathrm{E}\right)$. Specimens were transplanted to the same sites previously studied by RodolfoMetalpa et al. (2011): 1) station B1 at $3 \mathrm{~m}$ depth with a mean $\mathrm{pH}$ of $7.43 \pm 0.31$; 2) and station $\mathrm{C}$ at $5 \mathrm{~m}$ depth with a mean $\mathrm{pH}$ of $8.06 \pm 0.07$. At both sites corals were positioned calyx upwards inside an open cage made with two PVC plates $(60 \times 90 \mathrm{~cm})$, mounted using bolts and attached to $30 \mathrm{~kg}$ concrete blocks (Fig. 1a). The light irradiance received by the corals was $<10 \mu \mathrm{mol}$ photons $\mathrm{m}^{-2} \mathrm{~s}^{-1}$ as measured by a Li-Cor $4 \pi$ spherical underwater quantum sensor (LI-193SA). A Hobo Onset logger was positioned inside the cage to monitor seawater temperatures at 15 minute intervals for the entire duration of the transplantation. When checked on February $22^{\text {nd }} 2010$ the corals appeared healthy with fully expanded polyps that were sometimes seen catching organic detritus. A subsequent storm caused the loss of the cage at station $\mathrm{C}$ but corals at the high $\mathrm{CO}_{2}$ site appeared healthy and were collected on April $6^{\text {th }} 2010$, transported to the laboratory and weighed.

In March 2010, twenty-two samples of $D$. dianthus were suspended at $350 \mathrm{~m}$ depth on a mooring in Corsica channel (Aliani \& Meloni, 1999) using R/V Maria Grazia (CNR, Italy). The mooring had been anchored at $447 \mathrm{~m}$ depth $\left(43^{\circ} 01.76^{\prime} \mathrm{N}\right.$; $\left.09^{\circ} 41.12^{\prime} \mathrm{E}\right)$ since 1985 to monitor seawater temperature, salinity and currents. As at Ischia, corals were weighed and attached to individual plates, which were put into an open cage fixed to the mooring cable (Fig. 1b). Seawater samples were collected at the depth of the transplantation at the beginning (March 14 ${ }^{\text {th }}$ 2010) and at the end of the experiment (November $27^{\text {th }} 2010$ ) using Niskin bottles on a CTD-Rosette system. Details of the $\mathrm{pH}$ and total alkalinity measurements are reported below. Temperature, salinity, dissolved oxygen and currents were continuously recorded at 71, 121, 319, $408 \mathrm{~m}$ depth by the instruments positioned on the mooring (Aliani \& Meloni, 1999). Temperature at corals cage depth was $13.7^{\circ} \mathrm{C}( \pm 0.09)$, salinity was $38.6( \pm 0.14)$ and speed of current was $24 \mathrm{~cm} \mathrm{~s}^{-1}( \pm 15)$.

\section{Seawater carbonate chemistry}

Total alkalinity $\left(A_{\mathrm{T}}\right)$ and $\mathrm{pH}$ expressed on total scale $\left(\mathrm{pH}_{\mathrm{T}}\right)$ were measured from seawater samples collected: 1) on board R/V Urania in December 2008 and 2009; 2) at the mooring experiment at

This article is protected by copyright. All rights reserved. 
$350 \mathrm{~m}$ depth during transplantation; 3) at the coastal sites off Ischia, and 4) in the experimental aquaria. The $\mathrm{pH}_{\mathrm{T}}$ was measured immediately using a $\mathrm{pH}$-meter and an electrode (Methrom $\mathrm{pH}$ mobile) calibrated against the TRIS/HCl and 2-aminopyridine/ $\mathrm{HCl}$ buffer solutions. The seawater samples were then passed through Whatman $\mathrm{GF} / \mathrm{F}$, treated with $0.05 \mathrm{ml}$ of $50 \% \mathrm{HgCl}_{2}$ (Merck, Analar) and stored in glass bottles the dark at $4^{\circ} \mathrm{C}$ pending analysis. Three replicate of $20 \mathrm{ml}$ subsamples were analysed at $25^{\circ} \mathrm{C}$ using a titration system composed of a $\mathrm{pH}$ meter with a Methrom $\mathrm{pH}$ electrode and a $1 \mathrm{ml}$ automatic burette. Titration values of $A_{\mathrm{T}}$ standards provided by A.G. Dickson were within $0.5 \mu \mathrm{mol} \mathrm{\textrm {kg } ^ { - 1 }}$ of the nominal value.

The other parameters of the carbonate system $\left(\mathrm{pCO}_{2}, \mathrm{CO}_{3}{ }^{2-}, \mathrm{HCO}_{3}{ }^{-}, C_{\mathrm{T}}\right.$ and $\Omega_{\text {ara }}$ ) were calculated from $\mathrm{pH}_{\mathrm{T}}$, mean $A_{\mathrm{T}}$, temperature, pressure and mean salinity using the free-access $\mathrm{CO}_{2} \mathrm{SYS}$ package. Carbonate calculations were carried out using the recommended dissociation constants of carbonic acid in seawater $\left(\mathrm{K}_{1}\right.$ and $\mathrm{K}_{2}$ from Mehrbach et al., 1973 refitted by Dickson \& Millero, 1987). $A_{\mathrm{T}}$ and salinity were constant throughout the laboratory experiments. Averages of $\mathrm{pH}_{\mathrm{T}}$ were calculated from hydrogen ion concentrations of each measurement and then reconverted back to $\mathrm{pH}$ (Kerrison et al., 2011).

\section{Coral calcification and dissolution}

Net calcification rates (gross calcification minus dissolution) of the corals cultured in aquaria were measured during the acclimation period and after three months. At the beginning of the acclimation 46 specimens out of $80 \mathrm{D}$. dianthus, 14 out of $24 \mathrm{D}$. cornigera and 14 out of $24 \mathrm{C}$. smithii were randomly selected and weighed. All samples were weighed both at the end of the acclimation period and at the end of the experiment. In addition net calcification rates of $D$. dianthus were measured three days before and two days after the transplantation experiments. Corals were weighed using the buoyant weight technique (Davies, 1989) before and after being attached to tagged plastic plates. The difference (plate and glue weight) was recorded, for correction of the total weight. Samples were weighed in seawater of known density using a Mettler AT200 electronic balance with a precision of $0.1 \mathrm{mg}$. Measurement reproducibility of the buoyant weight system was $0.5 \mathrm{mg}(\mathrm{n}=10)$. The net buoyant weight of the corals was converted into dry weight using the density of the pure aragonite $\left(2.94 \mathrm{~g} \mathrm{~cm}^{-3}\right)$. Using this value we found that our estimations of coral calcification rates were only 5-8 \% higher than rates calculated from skeletal density measurements by Movilla et al. (2014a) for $D$. dianthus and D. cornigera. Daily

This article is protected by copyright. All rights reserved. 
growth rates were quantified as the change in dry weight during the incubations, and normalized to the initial dry weight of each specimen (i.e. $\mathrm{mg} \mathrm{CaCO}_{3} \mathrm{~g}^{-1}$ dry skeleton day ${ }^{-1}$ ). For comparison with other studies, buoyant weights of samples were also calculated in percentage per day (\% day $\left.^{-1}\right)$. The same approach as above was used to measure the skeletal dissolution rates of $D$. dianthus maintained in aquaria ( 7 specimens for each tank, $\mathrm{n}=14$ per treatment) for two months at normal and high $\mathrm{pCO}_{2}$ conditions.

Gross calcification rates (i.e. the amount of carbonate deposited by an animal over time, and unaffected by the skeletal dissolution) of corals maintained in aquaria under normal and high $p \mathrm{CO}_{2}$ conditions were measured at the end of the experiment using the ${ }^{45} \mathrm{Ca}$ technique (Tambutté et al., 1995). At the end of the incubation, four samples of each species from each tank $(\mathrm{n}=8$ per treatment) were transferred to four dedicated tanks (6 1 volume) set-up at the same experimental temperature $\left(13.4^{\circ} \mathrm{C}\right)$ and $p \mathrm{CO}_{2}$ conditions $\left(\mathrm{pH}_{\mathrm{T}}=8.07 ; p \mathrm{CO}_{2}=319 \mu \mathrm{atm} ; \mathrm{pH}_{\mathrm{T}}=7.70 ; p \mathrm{CO}_{2}=\right.$ $1058 \mu \mathrm{atm})$. After two days acclimation, the seawater renewal was halted and ${ }^{45} \mathrm{CaCl}_{2}$ was added in order to reach a final activity of $50 \mathrm{~Bq} \mathrm{ml}^{-1}$ in each aquarium. The seawater was renewed and spiked with radiotracer every day to maintain the same $\left[{ }^{45} \mathrm{Ca}\right]$. This was checked two times a day to determine radioactivity using glass vials containing $1 \mathrm{ml}$ of seawater collected from the aquaria and 10ml of scintillation liquid (Ultima Gold, PerkinElmer). After a week, all corals were collected and processed. At the end of the labelling period, samples were incubated in 61 tanks containing unlabelled seawater for one hour to achieve isotopic dilution of ${ }^{45} \mathrm{Ca}$ contained in the coral coelenterons. Samples were blotted dry and the tissue dissolved in 1 to $2 \mathrm{ml} 1 \mathrm{~N} \mathrm{NaOH}$ at $90^{\circ} \mathrm{C}$. Each sample was rinsed twice in $1 \mathrm{ml} \mathrm{NaOH}$ solution, dried, weighed and transferred onto individual pre-combusted glass vials. Coral skeletons were dissolved in $1.5 \mathrm{ml} 12 \mathrm{~N} \mathrm{HCl}$, the solutions were evaporated on a hot plate and $10 \mathrm{ml}$ of liquid scintillation medium was added to the radioactive samples. Beta emissions were measured using a liquid scintillation counter (2100 TR Packard; Tricarb). Calculations of calcification were based on a seawater calcium concentration (Tambutté et al., 1995) of $10 \mathrm{mM}$. Results were normalized to dry skeletal mass (i.e. nmol ${ }^{45} \mathrm{Ca} \mathrm{g}^{-1}$ dry skeleton $\mathrm{day}^{-1}$ ). Non-biological incorporation of ${ }^{45} \mathrm{Ca}$ (i.e. adsorption) on exposed skeletons (only present for samples of D. cornigera) was estimated using an identical protocol. The skeletons of dead D. dianthus were incubated and treated as those of the live

This article is protected by copyright. All rights reserved. 
samples. The amount of ${ }^{45} \mathrm{Ca}$ incorporated (less than $7 \%$ ) was subtracted from the total amount measured on live samples.

\section{Respiration}

Respiration rates were measured during the acclimation period and after 10 weeks of incubation. Each of the seven specimens of $D$. dianthus $(\mathrm{n}=14$ for each treatment), four D. cornigera $(\mathrm{n}=8$ for each treatment) and four $C$. smithii ( $\mathrm{n}=8$ for each treatment) was placed in closed thermostated Perspex chambers (ca. $100 \mathrm{ml}$ volume). Seawater used during the incubations was previously filtered at $0.20 \mu \mathrm{m}$ and then maintained at the treatment $p \mathrm{CO}_{2}$ and temperature conditions. Seawater in the chamber was continuously stirred with a stirring bar. Six chambers were immersed in a water bath connected to a Ministat 125 (Huber) kept at $13.5 \pm 0.2^{\circ} \mathrm{C}$. Changes in the concentration of dissolved oxygen were measured using a Strathkelvin oxygen electrode system (Clark-type electrodes connected to a Strathkelvin 928 oxygen meter and a computer). The electrode was calibrated against $\mathrm{O}_{2}$-free (using sodium dithionite) and airsaturated seawater. The $\mathrm{O}_{2}$ concentration at saturation was calculated according to the experimental temperature and the salinity values at the ambient barometric pressure (http://www.unisense.com/Default.aspx?ID=117). Prior to the measurements, the polyps were acclimated for at least $10 \mathrm{~min}$. The respiration rates were measured in the dark during 20-30 min incubations during which the corals were fully expanded. Seawater $\mathrm{pH}_{\mathrm{T}}$ was 8.07 and 7.70 at the beginning of the incubations (Table 1) and $8.05 \pm 0.02$ and $6.65 \pm 0.04$ at the end. Changes in dissolved $\mathrm{O}_{2}$ were also measured in chambers without polyps ( $\mathrm{n}=6$ for each treatment). All measurements were performed sequentially over a period of one day. Data were normalized to the coral skeleton weights (i.e. dry weights), which were calculated using the buoyant weight technique and expressed in $\mu \mathrm{mol} \mathrm{O} \mathrm{O}^{-1} \mathrm{~h}^{-1}$.

\section{Statistical analyses}

Mixed model GLMs were used to test the effects of $p \mathrm{CO}_{2}$ (fixed factor: normal and high), species (fixed factor where parameter studied in more than one species) and tanks (random factor: twothree levels) on the net, gross calcification, respiration (and dissolution for D. dianthus). Q-Q plots of residuals and Levene's homogeneity of variances tests were used to confirm conformity to analytical assumptions; net calcification data required a logarithmic transformation and 
respiration data a reflected logarithmic transformation to eliminate undesirable structure in residuals. Stepwise model simplification (criteria for removal of terms $=p>0.25, \Delta$ AIC $>2$ ) subsequently removed the random tank effect in all instances resulting in ordinary GLM analyses. Effects of $p \mathrm{CO}_{2}$ upon each parameter in each species independently were analysed using planned linear contrasts where the same parameter was examined in more than one species. The same approach was used to compare calcification and respiration rates of the three species measured during acclimation and at the end of the incubation (pooled data), as well as the net calcification of $D$. dianthus kept in the laboratory (pooled data), at $\mathrm{CO}_{2}$ seeps and at $350 \mathrm{~m}$ depth. To control for low experimental power due to small and unbalanced sample sizes in GLM analyses, observed power was calculated for the $\mathrm{CCO}_{2}$ effect for each species in each parameter tested and where low power $(<0.2 ; \alpha=0.05)$ was indicated the robustness of the analyses was examined by bootstrapping $(\mathrm{n}=500)$ to check for changes in inference based upon $p$ values; all test inferences were robust to bootstrapping. Differences in seawater carbonate chemistry parameters (High $\mathrm{CO}_{2}$ vs. Normal $\mathrm{CO}_{2}$ ) were tested using 1-way ANOVA. All the tests were performed using SPSS 21 (IBM Corp., New York). Data in the manuscript are reported as untransformed means \pm standard deviations.

\section{Results}

Seawater carbonate chemistry, calcification, dissolution and respiration rates in aquaria

All of the corals maintained in aquaria survived and had positive calcification rates after four months of incubation, including a one-month acclimation and a three-month experimental period (Fig. 2). Corals cultured in elevated $\mathrm{CO}_{2}$ conditions were exposed to seawater $p \mathrm{CO}_{2}(1058 \pm 168$ $\mu \mathrm{atm}), \mathrm{pH}_{\mathrm{T}}(7.70 \pm 0.06)$ and $\Omega_{\text {ara }}(1.29 \pm 0.17)$ values that significantly differed (one-way ANOVAs, $p<0.05$ ) from those at normal $p \mathrm{CO}_{2}$ treatment (Table 1). Both net and gross coral calcification rates, as measured using buoyant weight and ${ }^{45} \mathrm{Ca}$ techniques respectively, did not significantly differ between normal and high $p \mathrm{CO}_{2}$ treatments (GLM linear contrasts, $p>0.05$; Table 2). Net calcification rates of $D$. dianthus and $C$. smithii measured at the end of the experiment were not significantly different from calcification rates measured during the one month acclimation period (GLM linear contrasts, D. dianthus $\mathrm{F}_{1,158}=0.295, p=0.588$; C. smithii $\left.\mathrm{F}_{1,158}=0.041, p=0.839\right)$, and averaged $0.717 \pm 0.495$ and $1.726 \pm 0.606 \mathrm{mg} \mathrm{CaCO}_{3} \mathrm{~g}^{-1}$ dry

This article is protected by copyright. All rights reserved. 
skeleton day ${ }^{-1}$, respectively. In contrast, while during acclimation net calcification rate of $D$. cornigera was $1.125 \pm 0.320 \mathrm{mg} \mathrm{CaCO}_{3} \mathrm{~g}^{-1}$ dry skeleton day ${ }^{-1}$, it significantly decreased by a factor of four both at normal and high $p \mathrm{CO}_{2}\left(\mathrm{GLM}\right.$ linear contrast, $\left.\mathrm{F}_{1,158}=17.246, p<0.001\right)$. Gross calcification rates were measured at the end of the experiment, and averaged $774 \pm 352$ nmol ${ }^{45} \mathrm{Ca} \mathrm{g}^{-1}$ dry skeleton day ${ }^{-1}$ for $D$. dianthus, $1631 \pm 329 \mathrm{nmol}^{45} \mathrm{Ca} \mathrm{g}^{-1}$ dry skeleton day ${ }^{-1}$ for C. smithii, and $1168 \pm 311 \mathrm{nmol}^{45} \mathrm{Ca} \mathrm{g}^{-1} \mathrm{day}^{-1}$ for D. cornigera.

The skeleton dissolution rates of $D$. dianthus did not significantly differ between normal and high $p \mathrm{CO}_{2}$ treatments (GLM, $p>0.05$; Table 2) after two months of incubation. Coral dissolution rates were $0.042 \pm 0.091 \mathrm{mg}$ g dry $\mathrm{CaCO}_{3}{ }^{-1} \mathrm{day}^{-1}$ and $0.094 \pm 0.053 \mathrm{mg} \mathrm{g} \mathrm{dry} \mathrm{CaCO}_{3}{ }^{-1} \mathrm{day}^{-1}$ at the normal and high $\mathrm{pCO}_{2}$ respectively.

Respiration rate of $D$. dianthus measured during the acclimation month $\left(1.12 \pm 1.23 \mu \mathrm{mol} \mathrm{O}_{2} \mathrm{~g}^{-1}\right.$ $\mathrm{h}^{-1}$ ) was significantly lower (GLM linear contrast, $\left.\mathrm{F}_{1,96}=13.205, p<0.001\right)$ than after 10 weeks of incubation both at normal and high $p \mathrm{CO}_{2}$ treatments $\left(1.80 \pm 1.19\right.$ and $2.14 \pm 0.93 \mu \mathrm{mol} \mathrm{O}_{2} \mathrm{~g}^{-1}$ $\mathrm{h}^{-1}$ respectively; Fig. 3). In contrast, respiration rates of D. cornigera and $C$. smithii did not significantly change (GLM linear contrasts, D. cornigera $\mathrm{F}_{1,96}=0.769, p=0.384$; C. smithii $\mathrm{F}_{1,96}$ $=0.002, p=0.964$ ) and averaged $0.32 \pm 0.28$ and $0.63 \pm 0.41 \mu \mathrm{mol} \mathrm{O}_{2} \mathrm{~g}^{-1} \mathrm{~h}^{-1}$ respectively. Overall, $p \mathrm{CO}_{2}$ did not cause changes in the respiration rates of the three species (GLM linear contrasts, $p>0.05$; Table 2).

Seawater carbonate chemistry and net calcification rates of Desmophyllum dianthus transplanted in the field

All the specimens transplanted for 258 days at $350 \mathrm{~m}$ depth and for 43 days in aragonite undersaturated water off Ischia survived and grew. Seawater temperatures measured in continuous by temperature loggers at the mooring site and at $\mathrm{CO}_{2}$ seeps off Ischia were $13.72 \pm$ $0.09^{\circ} \mathrm{C}$ and $14.41 \pm 0.60^{\circ} \mathrm{C}$, respectively. Seawater $\mathrm{pH}$ and carbonate chemistry were significantly different between the two locations (one-way ANOVAs, $p<0.05$ ) with normal levels at the mooring site $\left(\mathrm{pH}_{\mathrm{T}} 8.02 ; p \mathrm{CO}_{2} 448 \mu \mathrm{atm}, \Omega_{\text {ara }} 2.58\right)$ and acidified conditions at the

This article is protected by copyright. All rights reserved. 
seep site $\left(\mathrm{pH}_{\mathrm{T}} 7.35 ; p \mathrm{CO}_{2} 2879 \mu \mathrm{atm}, \Omega_{\text {ara }}\right.$ 0.76; Table 1). Despite this large difference in carbonate chemistry, net calcification rates did not significantly differ between sites (GLM, $F_{1,31}$ $=0.007, p=0.932$ ), with values of $0.407 \pm 0.242$ and $0.414 \pm 0.208 \mathrm{mg} \mathrm{CaCO}_{3} \mathrm{~g}^{-1}$ dry skeleton day $^{-1}$ at the mooring and $\mathrm{CO}_{2}$ seeps, respectively. However, Desmophyllum dianthus in aquaria experienced significantly faster calcification rates compared to transplanted corals (GLM, $F_{1,90}=$ $12.208, p=0.001)$.

\section{Discussion}

Our observations in aquaria support recent studies showing that the calcification rates of coldwater coral species may not be affected by ocean acidification (Maier et al., 2012; 2013; Movilla et al., 2014b; Carreiro-Silva et al., 2014). We found that gross and net calcification rates of Desmophyllum dianthus, Caryophyllia smithii and Dendrophyllia cornigera, as well as dissolution rates of exposed skeleton and respiration rates of living $D$. dianthus, did not significantly change when exposed to high seawater $p \mathrm{CO}_{2}\left(\mathrm{pH}_{\mathrm{T}}=7.70 ; p \mathrm{CO}_{2}=1058 \mu\right.$ atm, $\Omega_{\text {ara }}$ $=1.29$ ). We tested this observation further by transplanting $D$. dianthus to $350 \mathrm{~m}$ depth at ambient seawater conditions $\left(\mathrm{pH}_{\mathrm{T}}=8.02 ; \mathrm{pO}_{2}=448 \mu \mathrm{atm} ; \Omega_{\text {ara }}=2.58\right)$ and into undersaturated seawater $\left(\mathrm{pH}_{\mathrm{T}}=7.35 ; p \mathrm{CO}_{2}=2879 \mu \mathrm{atm} ; \Omega_{\text {ara }}=0.76\right)$ near $\mathrm{CO}_{2}$ seeps and confirmed that net calcification rates were not affected by the differences in seawater carbonate chemistry. Feeding corals twice a week in aquaria, which is lower than several previous studies on CWC, increased their net calcification rates when compared to samples grown in situ. However, both corals in aquaria and in the field, artificially and naturally fed respectively, showed the same response to acidification: calcification rates were always unaffected by seawater carbonate chemistry.

\section{Calcification rates}

Carbonate solubility increases with decreasing temperature and increasing pressure, so aragonite saturation tends to be lower in deep and cold environments than in shallow warm waters. Coldwater coral reefs are being exposed to reduced aragonite saturation levels, raising great concerns about the future for these spectacular deep-sea habitats (Tittensor et al., 2010; Jackson et al., 2014). However, many such corals are known to be resistant to corrosive waters since they can grow below the aragonite saturation horizon and in acidified inshore waters (McCulloch et al.,

This article is protected by copyright. All rights reserved. 
2012b; Lunden et al., 2013; Thresher et al., 2011; Jantzen et al., 2013a,b). In the present study, three coral species calcified in aquaria at the same rates, regardless $p \mathrm{CO}_{2}$ treatment. Both gross and net calcification rates were positive, despite the fact that corals grew in seawater with low aragonite saturation $\left(\Omega_{\text {ara }} 1.29 \pm 0.17\right)$. Two mechanisms have been proposed to explain their ability to cope with low carbonate concentrations. Firstly, coral calcification occurs within the sub-calicoblastic space where the protein $\mathrm{Ca}^{2+}$ ATPase actively pumps $\mathrm{Ca}^{2+}$ ions from the coelenteron, in exchange for $2 \mathrm{H}^{+}$ions (e.g. Al-Horani et al., 2003; Cohen \& McConnaughey 2003). This exchange makes conditions favorable for calcification to occur by increasing $\mathrm{Ca}^{2+}$ concentration, $\mathrm{pH}$ and $\Omega_{\text {ara }}$ in the calcifying space (Allemand et al., 2011 and references therein). By measuring the boron isotope signature in the skeleton of several CWC species McCulloch et al. (2012b) showed that the corals are able to up-regulate $\mathrm{pH}$ at the site of calcification, with respect to the surrounding seawater, therefore facilitating calcification below the aragonite saturation horizon (see also Venn et al., 2013). Second, it has been suggested that at least tropical zooxanthellate corals can use either $\mathrm{HCO}_{3}{ }^{-}$directly to support their carbonate needs for calcification or indirectly by converting $\mathrm{HCO}_{3}{ }^{-}$to $\mathrm{CO}_{3}{ }^{-}$at the calcification site (e.g. Comeau et al., 2013). Coral sensitivity to acidification may also depend on calcification rates; slow-growing corals require less carbonate ions to grow so perhaps carbonate ion concentration is not a limiting factor (Rodolfo-Metalpa et al., 2010).

Net calcification rates of $C$. smithii and $D$. dianthus did not vary between a month at ambient $p \mathrm{CO}_{2}$ and three-month incubation at both ambient and high $p \mathrm{CO}_{2}$. In contrast, net calcification of D. cornigera decreased dramatically after acclimation, both at ambient and at high $p \mathrm{CO}_{2}$ conditions. Dendrophyllia cornigera calcified at $0.06 \pm 0.04 \%$ day $^{-1}$ during the acclimation period, which is very close to previously reported values for this species (0.04-0.05\% day $\left.{ }^{-1}\right)$ (Orejas et al., 2011; Naumann et al., 2013a,b), and slower s during the three month experiment (0.01-0.02\% day ${ }^{-1}$, pooled data). The decrease in the calcification rates was probably caused by the stress that the samples experienced during the preparation of the replicates from the mother colonies so our data on calcification rates for this species might be a husbandry artifact and should be taken with caution. Although speculative, it is possible that D. cornigera samples depleted lipid reserves during the acclimation period, being unable to sustain normal calcification rates during the incubation regardless the $p \mathrm{CO}_{2}$ treatment.

This article is protected by copyright. All rights reserved. 
This is the first study reporting the growth rate of $C$. smithii $\left(0.070-0.073 \%\right.$ day $\left.^{-1}\right)$ whereas the net calcification rates of $D$. dianthus has been already measured in six other studies. Overall, our results for both aquaria (0.023-0.024 \% day $\left.^{-1}\right)$ and in situ experiments (0.019-0.036\% day $\left.{ }^{-1}\right)$ agree with previously reported values for $D$. dianthus $\left(0.003-0.25 \%\right.$ day $\left.^{-1}\right)$ and for CWCs in general $\left(0.003-0.3 \%\right.$ day $\left.^{-1}\right)$. The $D$. dianthus specimens studied in the present study calcified six times slower than those cultured by Naumann et al. $(2011 ; 2013 b)\left(0.1-0.3 \%\right.$ day $\left.^{-1}\right)$ and by Jentzen et al. (2013a) (0.09\% day ${ }^{-1}$ ) but much faster than those cultured by Carreiro-Silva et al. (2014) $\left(0.004 \%\right.$ day $\left.^{-1}\right)$. The different feeding regimes used during these experiments likely influenced the calcification rates since scleractinian corals allocate a high proportion of the energy derived from food to calcification in tropical (Houlbréque \& Ferrier-Pagés, 2009) and cold-water environments (Naumann et al., 2011).

\section{Calcification rates in situ versus aquaria; the role of food}

To build their skeletons, corals pump protons out of the extracellular calcifying medium to increase internal $\mathrm{pH}$ and favour calcification. This is highly energy consuming (Allemand et al., 2011) with an estimated metabolic extra cost of ca. $10 \%$ per $0.1 \mathrm{pH}$ unit decrease in seawater $\mathrm{pH}$ (McCulloch et al., 2012b). To meet this energy demand, corals can increase feeding rates and/or draw upon energy reserves. Four previous studies have measured CWC net calcification, respiration rates, and lipid contents at high $\mathrm{pCO}_{2}$ (Hennige et al., 2013; Maier et al., 2013b; Carreiro-Silva et al., 2014; Movilla et al., 2014a). Hennige et al. (2013) found that respiration rates decreased while calcification rates remained the same in specimens of L. pertusa exposed to elevated $p \mathrm{CO}_{2}$; the other studies did not detect any effect of high $p \mathrm{CO}_{2}$ on coral respiration or calcification (Maier et al., 2013b; Carreiro-Silva et al., 2014; Movilla et al., 2014b) and lipid content (Movilla et al., 2014a). Even if a decrease in the lipid reserves would have been observed, such energy reallocation would only be successful until these lipid reserves run out, likely on a shorter time period than the ones tested during our experiments in aquaria and in the field. Corals could have also maintained elevated calcification rates by reallocating energy dedicated to other metabolic processes such as gamete production, gamete maturation, and spawning, for example. Studies on tropical corals showed that high $p \mathrm{CO}_{2}$ levels inhibit sperm motility, compromise their ability to move towards unfertilized eggs, therefore affecting fertilization efficiency, decrease larval metabolism and coral post-metamorphic growth (reviewed

This article is protected by copyright. All rights reserved. 
by Albright, 2011). Unfortunately, little is known on the reproductive cycle of CWC (references in Movilla et al., 2014) and no study has examined the impact of high $p \mathrm{CO}_{2}$ levels on CWC reproduction aspects.

In our aquarium experiments we also found that calcification and respiration rates were unaffected by acidification, but we suspect that the corals were able to maintain these metabolic rates thanks to the amount of food they received. Currently there is limited information on the natural feeding behavior of deep-sea corals; although we know they form reefs in food rich areas (Findlay et al., 2013), information on the effects of nutrition on cold-water coral metabolism are scarce. It has been experimentally shown that the CWC L. pertusa has an opportunistic feeding strategy and can change diet according to the external food source (Mueller et al., 2014). Up to now, all studies testing the resilience of CWC to ocean acidification used arbitrary feeding rates from no artificial feeding (Maier et al., 2012) to five times per week with Artemia nauplii and/or frozen Cyclops, Mysidacea, minced mussels, fish flakes (Tsounis et al., 2010; Orejas et al., 2011; Naumann et al., 2011; 2013a,b; Carreiro-Silva et al., 2014; Movilla et al., 2014a). Sometimes this diet was used for years before the experiment was carried out (e.g. Movilla et al., 2014a). Corals acclimated to such optimal feeding rates might have their metabolism and behavior completely changed, as well as their energy distribution. For instance, in the presence of artificial food in aquaria CWC tend to be permanently expanded, which is not the case in the field. Corals shown to calcify at reduced seawater $\Omega_{\text {ara }}$ (Maier et al., 2013a; Movilla et al., 2014a; CarreiroSilva et al., 2014) might only have been able to meet the extra energy demands as they were acclimated to abundant food conditions. This seems to be the case for tropical corals (Edmunds, 2011; Houlbrèque et al., 2015) and for mussels. Thomsen et al. (2013) elegantly demonstrated that only well fed mussels were able to calcify properly at high $p \mathrm{CO}_{2}$ levels.

To test whether the ocean acidification responses of artificially fed corals differed from naturally fed corals we transplanted them to field conditions with normal and elevated $p \mathrm{CO}_{2}$ where they were seen feeding naturally. In both cases the corals calcified at rates that were $44 \%$ lower than corals kept at similar temperature and $\mathrm{pH}$ in aquaria but artificially fed. Corals that we held in aquaria calcified faster than those in the field, likely due to greater food availability, but they were able to calcify at predicted levels of increased $p \mathrm{CO}_{2}$ both in the field and in the laboratory. Although we recognise that our transplantation experiments do not fully mimic natural

This article is protected by copyright. All rights reserved. 
environmental conditions, and that several factors (e.g. food quality, biological competition, hydrodynamics) affect corals calcification rates, this study is a first attempt to measure CWC calcification rates in the field. This helps validate the various aquarium-based observations that cold-water coral calcification is expected to be resilient to ocean acidification.

\section{Dissolution}

Coral skeletons are separated from the surrounding environment by soft tissue, allowing corals to create a semi-isolated space where calcification occurs (Allemand et al., 2011), and preventing dissolution in undersaturated seawater (Rodolfo-Metalpa et al., 2011). However, many scleractinians have large portions of their skeleton exposed to surrounding seawater, making tropical coral reefs (Fabricius et al., 2011) and cold-water coral reefs (Jackson et al., 2014) prone to chemical dissolution and bioerosion as oceans acidify. During our 2-month incubation in aquaria, dissolution rates measured using dead samples of $D$. dianthus did not significantly differ between normal and high $p \mathrm{CO}_{2}$ treatments. To the best of our knowledge, this is the first study measuring CWC dissolution. Rodolfo-Metalpa et al. (2011) showed that the dissolution of two temperate coral species kept in aquaria under controlled $p \mathrm{CO}_{2}$ conditions for 21 days, started only at $\mathrm{pHT}<7.4\left(\Omega_{\mathrm{ara}}=0.99 \pm 0.12\right)$. In contrast, van Woesik et al. (2013) measured significant dissolution at $\mathrm{pH} 7.8$ of several perforate and imperforate tropical coral skeletons but they used acetic acid to reach the desired $\mathrm{pH}$ which does not simulate ocean acidification conditions. In our laboratory experiments, skeletons were incubated for only two months, which was likely too short to measure significant differences in the dissolution rates between samples maintained under normal and high $p \mathrm{CO}_{2}$ conditions and never fell below $\Omega_{\text {ara }} 1$. However, we found no sign of dissolution on exposed skeletons of $D$. dianthus transplanted for 43 days at $\mathrm{CO}_{2}$ seeps off Ischia $\left(\Omega_{\text {ara }}=0.76 \pm 0.62\right)$ and this species grows well despite exposure of the skeleton to aragonite undersaturation in Chile (Försterra \& Häusserman, 2009). The time is ripe for experiments on the dissolution and bioerosion of cold-water corals to assess whether deep-sea reefs are as vulnerable to acidification as feared.

In summary, our observations in aquaria and in field transplants reveal that calcification is not the Achille's heel of cold-water corals facing ocean acidification. This is not to say that falling aragonite levels are of no concern, since acidification may cause disruptions to coral life cycles or

This article is protected by copyright. All rights reserved. 
widespread degradation of deep-water reef structures. Our study does not consider other likely detrimental factors such as global warming and hypoxia which might interact with acidification causing progressive ecosystem shifts (Pörtner et al., 2005; Lunden et al., 2014). Despite their global distribution, there are still huge gaps in our scientific understanding of the cold-water corals and their resilience to rapidly changing ocean conditions.

\section{Acknowledgements}

We thank the crews and the technicians aboard RVs Urania, Maria Grazia and Astrea. Special thanks to Saverio Devoti for assistance during coral collection. François Oberhaënsli and JeanFrançois Commanducci (IAEA) greatly helped during the experiment in aquaria and coral transplantations. The International Atomic Energy Agency is grateful to the Government of the Principality of Monaco for the support provided to its Environment Laboratories. This work contributes to the projects MISTRALS/ENVI-MED BITES and PaleoMex COFIMED. This is ISMAR-CNR Bologna scientific contribution n. 1854. The work contributes to the EU project: 'Mediterranean Sea Acidification under a changing climate' (MedSeA; grant agreement 265103).

\section{Figure legends}

Fig. 1. Transplantations of Desmophyllum dianthus on a rocky coast at $\mathrm{CO}_{2}$ seeps off Ischia (a) and suspended at $350 \mathrm{~m}$ depth on a mooring off Corsica (b).

Fig. 2. (a) Net and (b) gross calcification rates of the three Mediterranean cold-water corals held in aquaria during a one month acclimation period at normal $p \mathrm{CO}_{2}$ levels followed by three months at normal and increased $p \mathrm{CO}_{2}$ levels. Net calcification was also measured for $D$. dianthus transplanted to $350 \mathrm{~m}$ depth (Mooring) and at $\mathrm{CO}_{2}$ seeps. Data are mean $\pm \mathrm{SD}$. Replicates per treatment are: (a) Acclimation, $\mathrm{n}=14,14$ and 46; Normal and $\mathrm{High} p \mathrm{CO}_{2}, 8,8,40$ for C. smithii, D. cornigera and D. dianthus respectively; Mooring, 22 and $\mathrm{CO}_{2}$ seeps 11 D. dianthus. (b) Normal and $\mathrm{High} \mathrm{pCO}_{2}, \mathrm{n}=8$ each species.

Fig. 3. Respiration rates of three cold-water corals maintained in aquaria for one month at ambient seawater $p \mathrm{CO}_{2}$ (Acclimation) followed by three months at normal and increased $p \mathrm{CO}_{2}$

This article is protected by copyright. All rights reserved. 
(Normal and High $p \mathrm{CO}_{2}$ ). Data are mean $\pm \mathrm{SD}$. Replicates per treatment are: Acclimation, $\mathrm{n}=$ 10, 10 and 16; Normal and High $p \mathrm{CO}_{2}, 8,8,20$ for C. smithii, D. cornigera and D. dianthus respectively.

\section{References}

Albright R (2011) Reviewing the effects of ocean acidification on sexual reproduction and early life history stages of reef-building corals. Journal of Marine Biology, 2011 ID 473615, doi:10.1155/2011/473615.

Al-Horani FA, Al-Moghrabi SM, de Beer D (2003) The mechanism of calcification and its relation to photosynthesis and respiration in the scleractinian coral Galaxea fascicularis. Marine Biology 142(3), 419-426.

Aliani S, Meloni R (1999) Dispersal strategy of benthic species and water current variability in the Corsica Channel (western Mediterranean). Scientia Marina, 63(2), 137-145

Allemand D, Tambutté E, Zoccola D, Tambutté S (2011) Coral calcification cells to reefs. In Coral reefs: an ecosystem in transition (eds Z Dubinsky, N Stambler), pp. 119-150, Springer, Berlin Germany.

Carreiro-Silva M, Cerqueira T, Godinho A, Caetano M, Santos RS, Bettencourt R (2014) Molecular mechanisms underlying the physiological responses of the cold-water coral Desmophyllum dianthus to ocean acidification; Coral Reefs doi:101007/s00338-014-1129-2.

Cohen AL, McConnaughey TA (2003) Geochemical perspectives on coral mineralization. Reviews in Mineralogy and Geochemistry 54,151-187.

Comeau S, Edmunds PJ, Spindel NB, Carpenter RC (2013) The responses of eight coral reef calcifiers to increasing partial pressure of $\mathrm{CO}_{2}$ do not exhibit a tipping point. Limnology and Oceanography, 58(1), 388-398.

Davies PS (1989) Short-term growth measurements of corals using an accurate buoyant weighing technique. Marine Biology, 101, 389-395.

Dickson AG \& Millero FJ (1987) A comparison of the equilibrium constants for the dissociation of carbonic acid in seawater media. Deep-sea Research 34(1194), 1733-1743.

Dodds LA, Black KD, Orr H, Roberts JM (2009) Lipid bio-markers reveal geographical differences in food supply to the cold-water coral Lophelia pertusa (Scleractinia). Marine Ecology Progress Series, 397, 113-124.

This article is protected by copyright. All rights reserved. 
Dodds LA, Roberts JM, Taylor AC, Marubini F (2007) Metabolic tolerance of the cold- water coral Lophelia pertusa (Scleractinia) to temperature and dissolved oxigen change. Journal Experimental Marine Biology Ecology, 349, 205-214.

Edmunds PJ, (2011) Zooplanktivory ameliorates the effects of ocean acidification on the reef coral Porites spp. Limnology and Oceanography, 56, 2402-2410.

Erez J, Reynaud S, Silverman J, Schneider K, Allemand D (2011) Coral calcification under ocean acidification and global change In: Coral reefs: An ecosystem in transition (eds Z Dubinsky, N Stambler) Springer Berlin, Germany, pp 151-176.

Findlay HS, Artioli Y, Moreno Navas J, Hennige SJ, Wicks LC, Huvenne AI, Woodward EMS, Roberts JM (2014) Tidal downwelling and implications for the carbon biogeochemistry of cold-water corals in relation to future ocean acidification and warming. Global Change Biology 19, 2708-2719.

Fabricius KE, Langdon C, Uthicke S, et al. (2011) Losers and winners in coral reefs acclimatized to elevated carbon dioxide concentrations. Nature Climate Change, 1(3), 165-169.

Form AU, Riebesell U (2012) Acclimation to ocean acidification during long-term $\mathrm{CO}_{2}$ exposure in the cold-water coral Lophelia pertusa. Global Change Biology, 18, 843-853.

Försterra G, Häusserman V (2003) First report on large scleractinian (Cnidaria: Anthozoa) accumulations in cold-temperate shallow water of south Chilean fjord. Zoologische verhandelingen Leiden, 345, 117-128.

Guinotte JM, Orr JC, Cairns SS, Freiwald A, Morgan L, George R (2006) Will human-induced changes in seawater chemistry alter the distribution of deep-sea scleractinian corals? Frontier in Ecological Environment, 4, 141-146.

Hennige SJ, Wicks LC, Kamenos NA, Bakker DCE, Findlay HS, Dumousseaud C, Roberts JM (2013) Short-term metabolic and growth responses of the cold-water coral Lophelia pertusa to ocean acidification. Deep-Sea Research II, 99, 27-35.

Hoegh-Guldberg O, Mumby PJ, Hooten AJ, et al. (2007) Coral reefs under rapid climate change and ocean acidification. Science, 318(5857), 1737-1742.

Houlbrèque F, Ferrier-Pagés C (2009) Heterotrophy in tropical scleractinian corals. Biological Review 84, 1-17.

This article is protected by copyright. All rights reserved. 
Houlbrèque F, Reynaud S, Godinot C, Oberhänsli F, Rodolfo-Metalpa R, Ferrier-Pagès C (2015) Ocean acidification reduces feeding rates in the scleractinian coral Stylophora pistillata. Limnology and Oceanography 60(1) in press.

IPCC (2014) Climate Change 2014: Impacts, Adaptation, and Vulnerability. Part A: Global and Sectoral Aspects. Contribution of Working Group II to the Fifth Assessment Report of the Intergovernmental Panel on Climate Change [Field, C.B., V.R. Barros, D.J. Dokken, K.J. Mach, M.D. Mastrandrea, T.E. Bilir, M. Chatterjee, K.L. Ebi, Y.O. Estrada, R.C. Genova, B. Girma, E.S. Kissel, A.N. Levy, S. MacCracken, P.R. Mastrandrea, and L.L. White (eds.)]. Cambridge University Press, Cambridge, United Kingdom and New York, NY, USA.

Jackson EL, Davies AJ, Howell KL, Kershaw PJ, Hall-Spencer JM, (2014) Future-proofing marine protected area networks for cold water coral reefs. ICES Journal of Marine Science, doi:101093/icesjms/fsu099.

Jantzen C, Häussermann V, Försterra G, Laudien J, Ardelan M, Maier S, Richter C (2013a) Occurrence of cold-water coral along a natural $\mathrm{pH}$ gradients (Patagonia Chile). Marine Biology, 160, 2597-2607.

Jantzen C, Laudien J, Sokol S, Försterra G, Häussermann V, Kupprat F, Richter C (2013b) In situ short-term growth rates of cold water coral. Marine and Freshwater Research 64, 631-641.

Kerrison P, Hall-Spencer JM, Suggett DJ, Hepburn LJ, Steinke M (2011) Assessment of pH variability at a coastal $\mathrm{CO}_{2}$ vent for ocean acidification studies. Estuarine, Coastal and Shelf Science 94, 129-137.

Langdon C, Takahashi T, Sweeney C, Chipman D, Goddard J, Marubini F, Aceves H, Barnett H, Atkinson MJ (2000) Effect of calcium carbonate saturation state on the calcification rate of an experimental coral reef. Global Biogeochemistry Cycles, 14, 639-654.

Lunden JJ, Georgian SE, Cordes EE (2013) Aragonite saturation states of cold-water coral reefs structured by Lophelia pertusa in the northern Gulf of Mexico. Limnology and Oceanography, 58, 354-362.

Lunden JJ, McNicholl CG, Sears CR, Morrison CL, Cordes EE (2014) Acute survivorship of the deep-sea coral Lophelia pertusa from the Gulf of Mexico under acidification, warming, and deoxygenation. Frontiers in Marine Science 1:78. doi:10.3389/fmars.2014.00078.

This article is protected by copyright. All rights reserved. 
Maier C, Schubert A, Berunza Sànchez MM, Weinbauer MG, Watremez P, Gattuso JP (2013a) End of century $\mathrm{CCO}_{2}$ levels do not impact calcification in Mediterranean cold-water corals. PLOS ONE, 8(4), e62655.

Maier C, Bils F, Weinbauer MG, Watremez P, Peck MA, Gattuso JP (2013b) Respiration of Mediterraneean cold-water corals is not affected by ocean acidification as projected for the end of the century. Biogeosciences, 10, 5671-5680.

Maier C, Watremez P, Taviani M, Weinbauer MG, Gattuso JP (2012) Calcification rates and the effect of ocean acidification on Mediterranean cold-water corals. Proceedings of the Royal Society B, 279, 1716-1723.

McCulloch M, Falter J, Trotter J, Montagna P (2012a) Coral resilience to ocean acidification and global warming through $\mathrm{pH}$ up-regulation. Nature Climate Change, DOI: 101038/NCLIMATE1473.

McCulloch M, Trotter J, Montagna P, et al. (2012b) Resilience of cold-water scleractinian corals to ocean acidification: Boron isotopic systematic of $\mathrm{pH}$ and saturation state up-regulation. Geochimical and Cosmochimical Acta, 87, 21-34.

Mehrbach C, Culberson CH, Hawley JE, Pytkowicz RM (1973) Measurement of the apparent dissociation constants of carbonic acid in seawater at atmospheric pressure. Limnology and Oceanography 18, 897-907.

Movilla J, Orejas C, Calvo E, Gori A, López-Sanz A, Grinyó J, Domínguez-Carrio C, Pelejero C (2014a) Differential response of two Mediterranean cold-water coral species to ocean acidification. Coral Reefs, doi:101007/s00338-014-1159-9.

Movilla J, Gori A, Calvo E, Orejas C, López-Sanz A, Domínguez-Carrio C, Grinyó J, Pelejero C (2014b) Resistance of Two Mediterranean Cold-Water Coral Species to Low-pH Conditions Water, 6, 59-67; doi:10.3390/w6010059

Mueller CE, Larsson AI, Veuger B, Middelburg JJ, van Oevelen D (2014) Opportunistic feeding on various organic food sources by the cold-water coral Lophelia pertusa. Biogeosciences, 11, 123-133.

Naumann MS, Orejas C, Ferrier-Pagès C (2013a) High thermal tolerance of two Mediterranean cold-water coral species maintained in aquaria. Coral Reefs, 32, 749-754.

This article is protected by copyright. All rights reserved. 
Naumann MS, Orejas C, Ferrier-Pagès C (2013b) Species-specific physiological response by cold-water corals Lophelia pertusa and Madrepora oculata to variations within their natural temperature range. Deep-Sea Research Part II, 99, 36-41.

Naumann MS, Orejas C, Wild C, Ferrier-Pagès C (2011) First evidence for zooplankton feeding sustaining key physiological processes in a scleractinian cold-water coral. The Journal of Experimental Biology, 214, 3570-3576.

Orejas C, Ferrier-Pagès C, Reynaud S, Gori A, Beraud E, Tsounis G, Allemand D, Gili JM (2011) Long-term growth rates of four Mediterranean cold-water coral species maintained in aquaria. Marine Ecology Progress Series, 429, 57-65.

Orr JC, Fabry VJ, Aumount O et al. (2005) Anthropogenic ocean acidification over the twentyfirst century and its impact on calcifying organisms. Nature, 437, 681-686.

Pörtner HO, Lungenbuch M, Michaelidis B (2005) Synergistic effects of temperature extremes, hypoxia, and increases in $\mathrm{CO}_{2}$ on marine animals: From Earth history to global change. Journal of Geophysical Research, 110, C09S10, doi:10.1029/2004JC002561.

Roberts JM, Wheeler A, Freiwald A, Cairns SD (2009) Cold-water Corals: The Biology and Geology of Deep-sea Coral Habitats. University Press, Cambridge.

Rodolfo-Metalpa R, Houlbrèque F, Tambutté E, et al. (2011) Coral and mollusc resistance to ocean acidification adversely affected by warming. Nature Climate Change, 1, 308-312.

Rodolfo-Metalpa R, Martin S, Ferrier-Pagés C, Gattuso JP (2010) Response of the temperate coral Cladocora caespitosa to mid- and long-term exposure to $p \mathrm{CO}_{2}$ and temperature levels projected for the year 2100 AD. Biogeosciences 7, 289-300.

Tambutté E, Allemand D, Bourge I, Gattuso JP, Jaubert J (1995) An improved ${ }^{45}$ Ca protocol for investigatingphysiological mechanisms in coral calcification. Marine Biology, 122, 453-459.

Thomsen J, Casties I, Pansch C, Körtzinger A, Melzner F (2013) Food availability outweighs ocean acidification effects in juvenile Mytilus edulis: laboratory and field experiments. Global Change Biology, 19, 1017-1027.

Thresher RE, Tilbrook BD, Fallon S, Wilson NC, Adkins J (2011) Effects of chronic low carbonate saturation levels on the distribution growth and skeletal chemistry of deep-sea corals and other seamount megabenthos. Marine Ecology Progress Series, 442, 87-99.

Tittensor DP, Baco AR, Hall-Spencer JM, Orr JC, Rogers AD (2010) Seamounts as refugia from ocean acidification for cold-water stony corals. Marine Ecology, 31, 212-225.

This article is protected by copyright. All rights reserved. 
Tsounis G, Orejas C, Reynaud S, Gili JM, Allemand D, Ferrier-Pagès C (2010) Capture rates by four Mediterranean deep corals. Marine Ecology Progress Series, 398, 149-155.

van Woesik R, van Woesik K, van Woesik L, van Woesik S (2013) Effects of ocean acidification on the dissolution rates of reef-coral skeletons. PeerJ, 1:e208.

Venn AA, Tambutte E, Holcomb M, Laurent J, Allemand D, Tambutte S (2013) Impact of seawater acidification on $\mathrm{pH}$ at the tissue-skeleton interface and calcification in reef corals. Proceeding of the National Academy of Science of the United States of America, 110, 16341639.

Table 1. Mean $( \pm \mathrm{SD})$ seawater temperatures, $\mathrm{pH}_{\mathrm{T}}$ and total alkalinity $\left(A_{\mathrm{T}}\right)$ measured during the collection of corals (Cruises ARCO and MEDCOR), during experiment in aquaria (acclimation, normal and high $p \mathrm{CO}_{2}$; pooled data between replicated tanks), and during coral transplantation and recover on the mooring and at $\mathrm{CO}_{2}$ seeps. Data in square brackets represent the number of measurements. $A_{\mathrm{T}}$ replicates were $\mathrm{n}=2,18,36,36,5$, and 4 for ARCO, acclimation, normal, high p $\mathrm{CO}_{2}$, in situ $350 \mathrm{~m}$, and in situ $\mathrm{CO}_{2}$ seeps respectively. Data for MEDCOR St 30 are from Maier et al. (2013a). Mean $\mathrm{pH}$ was calculated after conversion of data to hydrogen ion concentrations.

\begin{tabular}{|c|c|c|c|c|c|c|c|c|c|}
\hline Treatment [n] & $\mathbf{T}\left({ }^{\circ} \mathrm{C}\right)$ & $\begin{array}{l}\text { Depth } \\
(\mathrm{m})\end{array}$ & $\mathbf{p H}_{\mathrm{T}}$ & $\begin{array}{c}\boldsymbol{A}_{\mathbf{T}} \\
\mu \mathrm{mol} \mathrm{kg}\end{array}$ & $\underset{\mu \mathrm{atm}}{\boldsymbol{p} \mathbf{C O}_{2}}$ & $\begin{array}{c}\mathbf{C O}_{2} \\
\mu \mathrm{mol} \mathrm{kg}\end{array}$ & $\begin{array}{c}\mathbf{C O}_{3}{ }^{\mathbf{2 -}} \\
\mu \mathrm{mol} \mathrm{kg}\end{array}$ & \multicolumn{2}{|c|}{$\underset{\mu \mathrm{mol} \mathrm{kg}}{\mathbf{H C O}_{3}^{-}} \quad \mathbf{\Omega}_{\text {arag }}$} \\
\hline ARCO St 3 [1] & 13.8 & 1000 & 7.99 & 2629 & 483 & 18 & 184 & 2179 & 2.34 \\
\hline ARCO St 4 [1] & 13.6 & 800 & 7.98 & 2608 & 503 & 19 & 182 & 2164 & 2.40 \\
\hline MEDCOR St 30 [1] & 12.7 & 690 & & 2623 & 349 & 14 & 210 & 2104 & 2.80 \\
\hline \multirow[t]{2}{*}{ Acclimation [35] } & 13.2 & - & 60 & 2476 & 419 & 16 & 175 & 2082 & 2.62 \\
\hline & $(0.2)$ & & $(0.03)$ & $(11)$ & $(30)$ & (1) & (9) & $(23)$ & $(0.14)$ \\
\hline \multirow[t]{2}{*}{ Normal pH [103] } & 13.4 & - & 8.07 & 2514 & 399 & 16 & 182 & 2066 & 2.72 \\
\hline & $(0.2)$ & & $(0.04)$ & $(44)$ & $(38)$ & (1) & $(13)$ & $(32)$ & $(0.19)$ \\
\hline \multirow[t]{2}{*}{ High $p \mathrm{CO}_{2}[103]$} & 13.4 & - & 7.70 & 2481 & 1058 & 41 & 86 & 2302 & 1.29 \\
\hline & $(0.3)$ & & $(0.06)$ & (28) & $(168)$ & (7) & (12) & $(28)$ & $(0.17)$ \\
\hline \multirow[t]{2}{*}{ In situ mooring [6] } & 13.6 & 350 & 8.02 & 2599 & 448 & 17 & 182 & 2152 & 2.58 \\
\hline & $(0.1)$ & & $(0.03)$ & (10) & (42) & (2) & (12) & (31) & $(0.18)$ \\
\hline \multirow[t]{2}{*}{ In situ $\mathrm{CO}_{2}$ seeps [5] } & ] 13.9 & 3 & 7.35 & 2563 & 2879 & 109 & 51 & 2438 & 0.76 \\
\hline & $(0.8)$ & & $(0.28)$ & $(0.3)$ & (1362) & (52) & $(42)$ & $(108)$ & $(0.62)$ \\
\hline
\end{tabular}

This article is protected by copyright. All rights reserved. 


\section{Table 2.}

Summary of GLM (Dissolution in Desmophyllum dianthus) or GLM linear contrasts testing the effect of two levels of $p \mathrm{CO}_{2}$ (normal and high) on corals' physiological parameters in aquaria. NC: net calcification $(\operatorname{Ln}(\mathrm{x})$ transformed); GC: gross calcification; Respiration (reflected $\operatorname{Ln}(\mathrm{x})$ transformed).

\begin{tabular}{|c|c|c|c|c|}
\hline Factors & $(d f)$ & $S S$ & F-ratio & P-value \\
\hline \multicolumn{5}{|c|}{ NC Caryophyllia smithii } \\
\hline $\mathrm{pH}$ & (1) & 0.080 & 0.236 & 0.628 \\
\hline Error & (84) & 28.646 & & \\
\hline \multicolumn{5}{|c|}{ NC Dendrophyllia cornigera } \\
\hline $\mathrm{pH}$ & (1) & 0.007 & 0.019 & 0.890 \\
\hline Error & (84) & 28.646 & & \\
\hline \multicolumn{5}{|c|}{ NC Desmophyllum dianthus } \\
\hline $\mathrm{pH}$ & (1) & 0.079 & 0.023 & 0.633 \\
\hline Error & (84) & 28.646 & & \\
\hline \multicolumn{5}{|c|}{ GC Caryophyllia smithii } \\
\hline $\mathrm{pH}$ & (1) & $2.51 \mathrm{E}+05$ & 2.330 & 0.134 \\
\hline Error & (42) & $4.52 \mathrm{E}+06$ & & \\
\hline \multicolumn{5}{|c|}{ GC Dendrophyllia cornigera } \\
\hline $\mathrm{pH}$ & (1) & $1.51 \mathrm{E}+05$ & 1.404 & 0.243 \\
\hline Error & (42) & $4.52 \mathrm{E}+06$ & & \\
\hline \multicolumn{5}{|c|}{ GC Desmophyllum dianthus } \\
\hline $\mathrm{pH}$ & (1) & $1.34 \mathrm{E}+04$ & 0.125 & 0.726 \\
\hline Error & (42) & $4.52 \mathrm{E}+06$ & & \\
\hline \multicolumn{5}{|c|}{ Dissolution Desmophyllum dianthus } \\
\hline $\mathrm{pH}$ & (1) & 0.018 & 3.16 & 0.087 \\
\hline Error & (25) & 0.142 & & \\
\hline \multicolumn{5}{|c|}{$\mathrm{O}_{2}$ respiration Caryophyllia smithii } \\
\hline $\mathrm{pH}$ & (1) & 0.001 & 0.005 & 0.942 \\
\hline Error & $(56)$ & 3.440 & & \\
\hline \multicolumn{5}{|c|}{$\mathrm{O}_{2}$ respiration Dendrophyllia cornigera } \\
\hline $\mathrm{pH}$ & (1) & 0.004 & 0.072 & 0.789 \\
\hline Error & (56) & 3.440 & & \\
\hline \multicolumn{5}{|c|}{$\mathrm{O}_{2}$ respiration Desmophyllum dianthus } \\
\hline $\mathrm{pH}$ & (1) & 0.060 & 0.982 & 0.326 \\
\hline Error & $(56)$ & 3.440 & & \\
\hline
\end{tabular}

This article is protected by copyright. All rights reserved. 


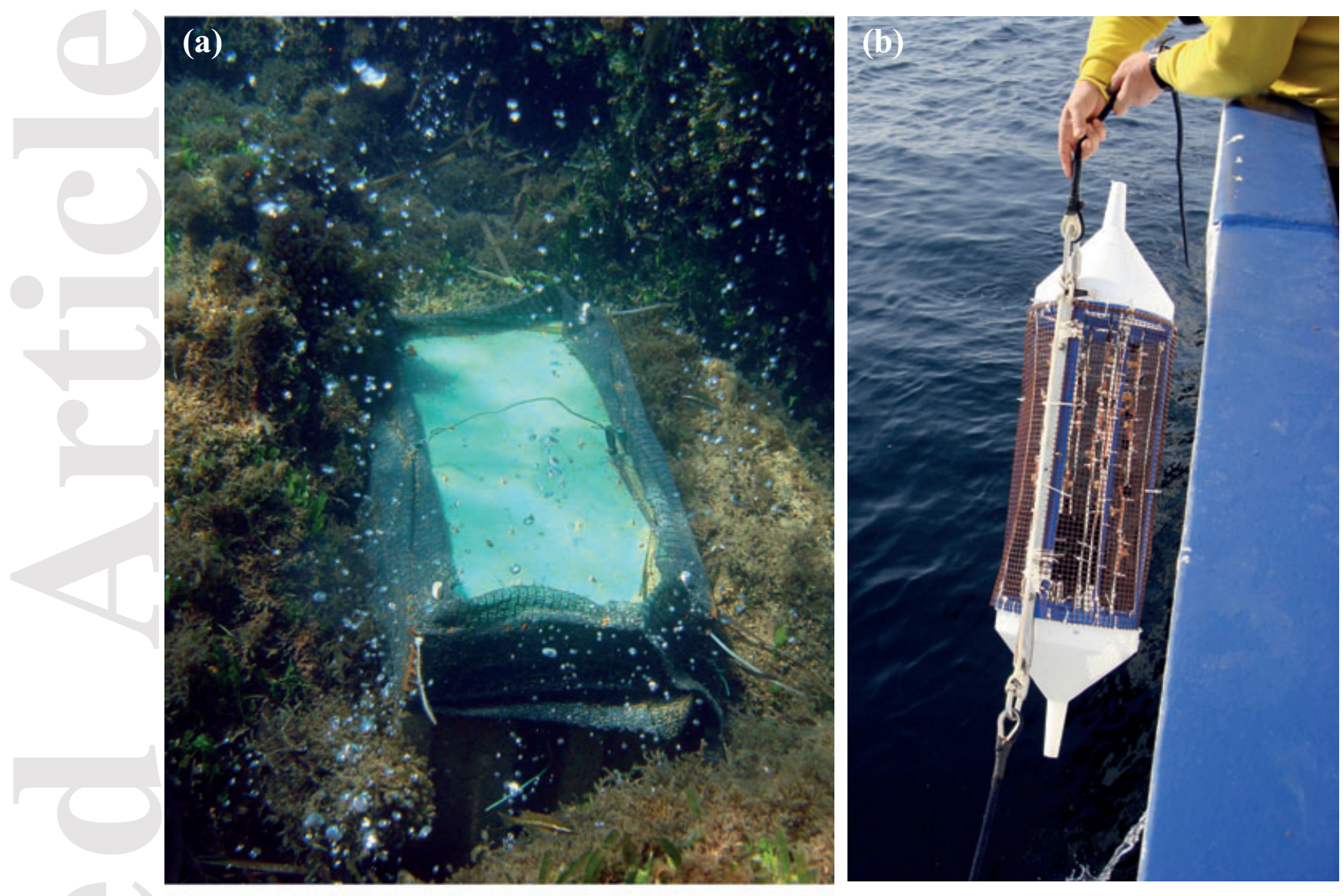

This article is protected by copyright. All rights reserved. 
(a)
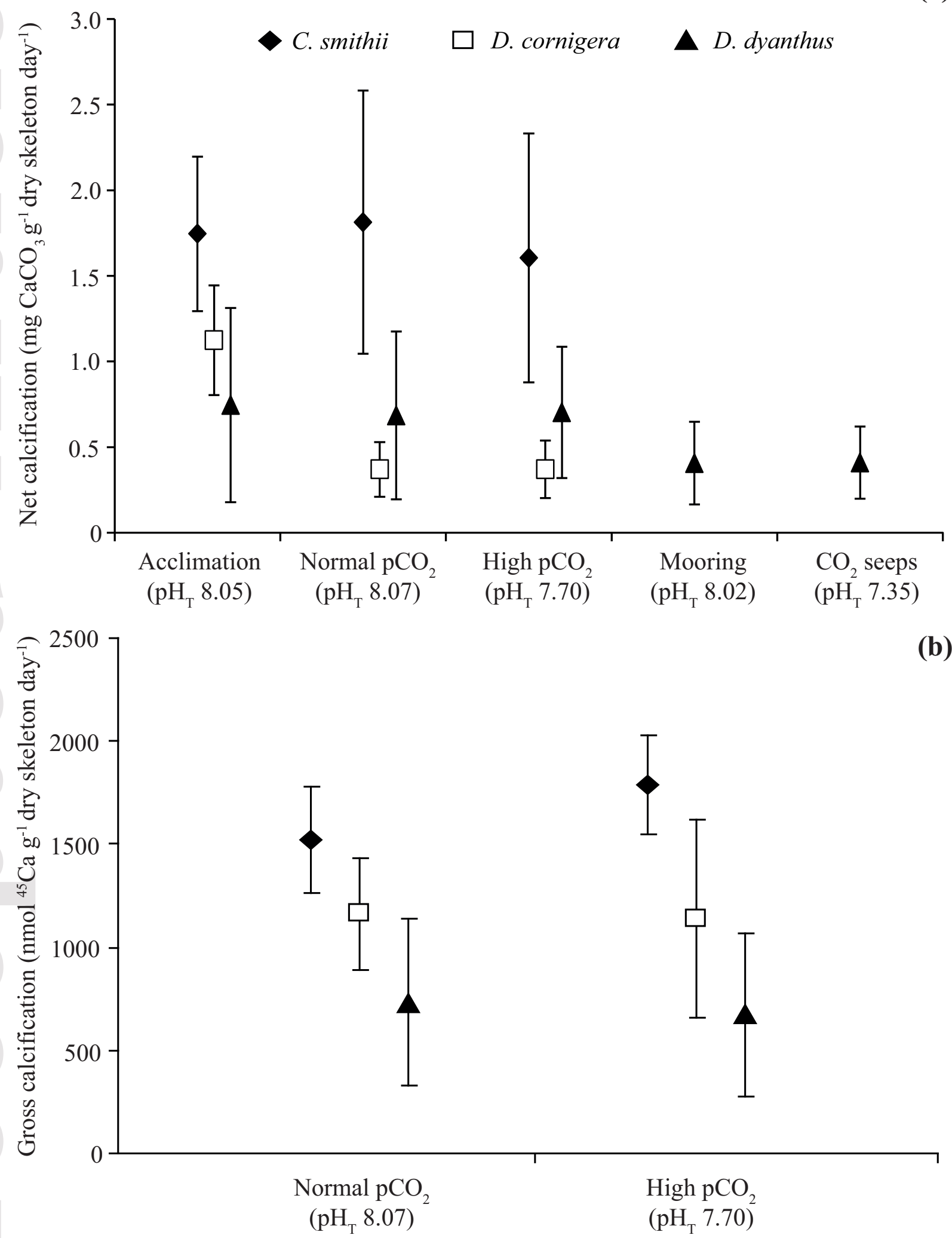

This article is protected by copyright. All rights reserved. 


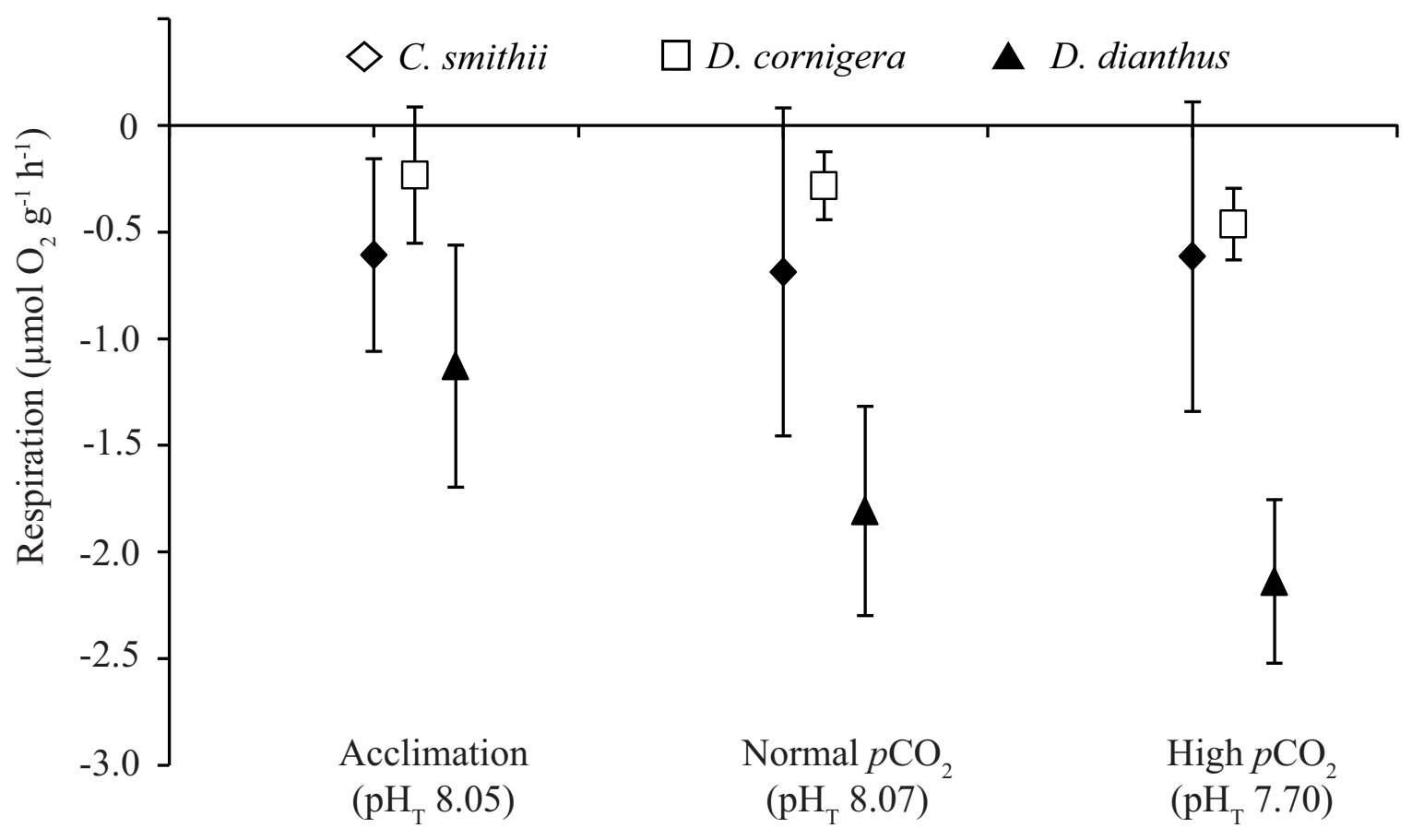

This article is protected by copyright. All rights reserved. 